DOI: https://doi.org/10.31933/jimt.v2i4 Received: 22 Januari 2021, Revised: 25 Februari 2021, Publish: 17 Maret 2021

JIMT
JUINASTI

\title{
FAKTOR YANG MEMPENGARUHI KINERJA PEGAWAI (SUATU KAJIAN STUDI LITERATUR MANAJEMEN SUMBER DAYA MANUSIA)
}

\author{
Mellysa Pusparani ${ }^{1}$ \\ 1) Mahasiswa Program Pascasarjana, Universitas Terbuka UPBJJ - UT Jambi, email: \\ mellysapusparani250578@gmail.com
}

Abstrak: Riset terdahulu atau riset yang relevan sangat penting dalam suatu riset atau artikel ilmiah. Riset terdahulu atau riset yang relevan berfungsi untuk memperkuat teori dan penomena hubungan atau pengaruh antar variable. Artikel ini mereview faktor yang mempengaruhi kinerja pegawai melalui lingkungan kerja, kepuasan kerja, dan komitmen organsiasi, Suatu Studi Literatur Manajemen Sumberdaya Manusia. Hasil dari library risearch ini adalah bahwa: 1) lingkungan kerja berpengaruh terhadap kinerja pegawai; 2) kepuasan kerja berpengaruh terhadap kinerja pegawai; 3) dan komitmen organisasi berpengaruh terhadap kinerja pegawai.

Kata Kunci: Kinerja, Lingkungan Kerja, Kepuasan Kerja, dan Komitmen Organisasi.

\section{PENDAHULUAN}

Setiap organisasi apapun bentuknya, baik organisasi bisnis, organisasi pemerintahan maupun organisasi sosial, selalu ingin mencapai beberapa tujuan. Tujuan-tujuan tersebut dapat dicapai dengan menggunakan sumberdaya manusia dan sumberdaya organisasi lainya seperti dana, bahan dan peralatan secara efektif dan efisien. Salah satu sumberdaya organisasi yang memainkan peran penting dalam pencapaian tujuan organisasi adalah sumberdaya ini belum dapat digantikan sepenuhnya oleh sumberdaya organisasi lainya. Sumber daya manusia sangat menentukan bagi keberhasilan dari organisasi tersebut (Dessler, 2017).

Salah satu aspek pokok dari pekerjaan manajemen yang berkaitan dengan sumberdaya manusia adalah aspek yang berkaitan dengan kinerja pegawai dan bagian manajemen yang mengelola ini lebih dikenal dengan sebutan manajemen kinerja. Dari literatur manejemen diketahui beragam konsep tentang kinerja (performance). Pada umumnya, mengacu pada hasil (prestasi atau penampilan) kerja yang dicapai oleh orang atau kelompok orang dalam suatu organisasi (perusahaan) berdasarkan satuan waktu atau ukuran tertentu. Pemahaman seperti ini mengandung penafsiran yang luas, terutama dari segi pendekatan dan ruang lingkup kajiannya serta penggunaan kriteria atau indikator untuk menentukan prestasi atau penampilan kerja. Pendefinisian kinerja yang mengacu pada pencapaian hasil (prestasi atau penampilan) kerja, dari segi pendekatan dan ruang lingkup kajiannya dimungkinkan dapat dilakukan dari aspek individual atau organisasial. 
Kinerja sangat penting bagi sebuah organisasi karena ia akan menentukan efektifitas dari organisasi tersebut, kinerja juga penting karena ia mencerminkan ukuran keberhasilan pada manejer dalam mengelola organisasi dan sumber daya manusianya. Tujuan-tujuan organisasi akan dapat dicapai melalui kinerja yang baik dari para pegawainya. Sebaliknya, organisasi akan menghadapi hambatan dalam mencapai tujuan-tujuanya manakala kinerja para pegawai tidak efektif, dalam arti tidak dapat memenuhi tuntutan-tuntutan pekerjaan yang diinginkan oleh organisasi.

Bagi pimpinan organisasi, kinerja pegawai menjadi sangat penting karena ia merupakan tolak ukur bagi keberhasilannya dalam mengelola unit kerja yang dipimpinnya. Jadi, kinerja merupakan faktor sentral bagi pekerjaan manajemen dalam mengelola organisasi. Karena itu, adalah penting bagi manajemen untuk mengenali dan memahami berbagai aspek yang berkaitan dengan kinerja pegawai baik faktor-faktor akibatnya (Anwar Prabu, 2017).

Berdasarakan latar belakang akan di rumuskan masalah yang akan di bahas pada artikel literature review agar lebih focus pada kajian pustaka dan hasil serta pembahasan nanti, yaitu: 1) Apakah lingkungan kerja berpengaruh terhadap kinerja pegawai?; 2) Apakah kepuasan kerja berpengaruh terhadap kinerja pegawai?; dan Apakah komitmen organisasi berpengaruh terhadap kinerja pegawai?

\section{KAJIAN PUSTAKA}

\section{Kajian Teori \\ a. Kinerja}

Kinerja merupakan suatu fungsi dari motivasi dan kemampuan untuk menyelesaikan tugas atau pekerjaan seseorang sepatutnya memiliki derajat kesediaan dan tingkat kemampuan tertentu. Kesediaan dan keterampilan seseorang tidaklah cukup efektif untuk mengerjakan sesuatu tanpa pemahaman yang jelas tentang apa yang akan dikerjakan dan bagaimana mengerjakannya. Kinerja merupakan perilaku nyata yang ditampilkan setiap orang sebagai prestasi kerja yang dihasilkan oleh karyawan sesuai dengan perannya dalam organisasi. Kinerja karyawan merupakan suatu hal yang sangat penting dalam upaya organisasi untuk mencapai tujuan (rivai dan sagala, 2011).

Menurut (Hasibuan, 2016) mendefinisikan kinerja sebagai suatu hasil kerja yang dicapai seseorang dalam melaksanakan tugas-tugas yang dibebankan kepadanya yang didasarkan atas kecakapan, pengalaman, kesungguhan serta waktu. Selain itu (Gomes, 2003) mendefinisikan kinerja adalah unjuk kerja yang merupakan hasil dari kerja yang dihasilkan oleh pegawai atau prilaku nyata yang ditampilkan sesuai dengan perannya dalam organisasi.

Secara teori terdapat banyak faktor yang mempengaruhi kinerja seseorang. Menurut (Simanjuntak, 2005) kinerja dipengaruhi oleh: 1) Kualitas dan kemampuan pegawai; 2) Sarana pendukung; dan 3) Supra sarana. Menurut (Sedarmayanti, 2017), faktor-faktor yang mempengaruhi kinerja antara lain :1) Sikap dan mental (motivasi kerja, disiplin kerja, dan etika kerja), 2) Pendidikan, 3) Keterampilan, 4) Manajemen kepemimpinan, 5) Tingkat penghasilan, 6) Gaji dan kesehatan, 7) Jaminan sosial, 8) Iklim kerja, 9) Sarana dan prasarana, 10) Teknologi, dan 11) Kesempatan berprestasi. Sedangkan menurut (Mathis \& Jackson, 2012) dalam pembahasan mengenai permasalahan kinerja karyawan maka tidak terlepas dari berbagai macam faktor yang menyertai diantaranya: 1) Faktor kemampuan (ability); dan 2) Faktor motivasi. 
Menurut (rivai dan sagala, 2011) adapun aspek-aspek yang dinilai untuk mengukur kinerja seseorang berdasarkan hasil studi Lazer dan Wikstrom (1997) dapat dikelompokkan menjadi tiga yaitu: 1) Kemampuan teknis; 2) Kemampuan konseptual; dan 3) Kemampuan hubungan interpersonal. Sedangkan menurut (Anwar Prabu, 2017), Kinerja karyawan dapat dinilai dari : 1) Kualitas kerja; 2) Kuantitas kerja; 3) Tanggung jawab; 4) Kerjasama; dan 5) Inisiatif.

\section{b. Lingkungan Kerja}

Lingkungan kerja adalah segala sesuatu yang ada disekitar para pekerja yang dapat mempengaruhi dirinya dalam menjalankan tugas-tugas yang diembankan (Nitisemito \& Alex, 2001). Menurut (Sedarmayanti, 2017) lingkungan kerja adalah keseluruhan alat perkakas dan bahan yang dihadapi, lingkungan sekitarnya di mana seseorang bekerja, metode kerjanya, serta pengaturan kerjanya baik sebagai perseorangan maupun sebagai kelompok. Menurut (Hasibuan, 2016) lingkungan kerja sebagai berikut: Lingkungan kerja adalah segala sesuatu yang ada di sekitar para pekerja yang dapat mempengaruhi drinya dalam menjalankan tugastugas yang diembankan.

Menurut Sarwoto dalam (Sedarmayanti, 2017) menyatakan bahwa secara garis besar, jenis lingkungan kerja terbagi menjadi 2 yakni : Lingkungan tempat kerja/Lingkungan kerja fisik (physical working environment); dan Suasana kerja/Lingkungan kerja non fisik (Non Phisical Warking Environment). Menurut (Sedarmayanti, 2017), "Lingkungan kerja fisik adalah semua keadaan berbentuk fisik yang terdapat di sekitar tempat kerja yang dapat mempengaruhi karyawan baik secara langsung maupun scara tidak langsung. Sedangkan menurut (Sedarmayanti, 2017) lingkungan kerja non fisik adalah semua keadaan yang terjadi yang berkaitan dengan hubungan kerja, baik hubungan dengan atasan maupun hubungan sesama rekan kerja, ataupun hubungan dengan bawahan.

Menurut (Nitisemito \& Alex, 2001) sebuah hendaknya dapat mencerminkan kondisi yang mendukung kerja sama antara tingkat atasan, bawahan maupun yang memiliki status jabatan yang sama di perusahaan. Kondisi yang hendaknya diciptakan adalah suasana kekeluargaan, komunikasi yang baik, dan pengendalian diri.

Lingkungan kerja mempunyai pengaruh terhadap karyawan perusahaan dalam usaha untuk menyelesaikan tugas-tugas yang dibebankan kepadanya, yang pada akhirnya berpengaruh terhadap disiplin kerja karyawan. Lingkungan kerja yang baik dan memuaskan karyawan tentu akan meningkatkan kinerja dari karyawan itu sendiri. Sehingga mereka dapat menyelesaikan tugas yang dibebankan dengan baik dan penuh tanggung jawab. Demikian juga sebaliknya bila lingkungan kerja kurang memuaskan bagi karyawan menyebabkan karyawan bekerja dalam suasana yang kurang tenang, sehingga akan dapat mempertinggi tingkat kesalahan yang mereka lakukan. Menurut (Sedarmayanti, 2017) adapun faktor yang dapat mempengaruhi kondisi lingkungan kerja, diantaranya adalah: 1) Penerangan/Cahaya di Tempat Kerja; 2) Temperatur di Tempat Kerja; 3) Kelembaban di Tempat Kerja; 4) Sirkulasi Udara di Tempat Kerja; 5) Kebisingan di Tempat Kerja; 6) Bau-bauan di Tempat Kerja; 7) Tata Warna di Tempat Kerja; 8) Dekorasi di Tempat Kerja; 9) Musik di Tempat Kerja; dan 10) Keamanan di Tempat Kerja.

\section{c. Kepuasan Kerja}

Setiap orang yang bekerja mengharapkan memperoleh kepuasan tempatnya bekerja. Pada dasarnya kepuasan kerja merupakan hal yang bersifat individual karena setiap individu 
akan memiliki tingkat kepuasan yang berbeda-beda sesuai dengan nilai-nilai yang berlaku dalam diri setiap individu. Semakin banyak aspek dalam pekerjaan yang sesuai dengan keinginan individu, maka semakin tinggi pula tingkat kepuasan yang dirasakan.

Pangabean dalam (Triatna, 2015) mendefinisikan kepuasan kerja merupakan tingkat keserasian antara apa yang diharapkan dengan apa yang dapat diperoleh, atau antara kebutuhan dan penghargaan. Sedangkan Menurut Robbin dalam (Sopiah, 2015) memaknai kepuasan kerja sebagai sikap umum terhadap pekerjaan seseorang yang menunjukan perbedaan antara jumlah penghargaan yang diterima pekerja dan jumlah mereka yakini seharusnya diterima.

Selain itu (Rivai Veitzhal, 2013) mendefinisikan kepuasan kerja merupakan evaluasi yang menggambarkan seseorang atas perasaan sikapnya senang atau tidak senang, puas atau tidak puas dalam bekerja. Lebih lanjut (McShane \& Von Glinow, 2018) mendefinisikan kepuasan kerja merupakan evaluasi individu tentang tugas dan konteks pekerjaannya. Kepuasan kerja terkait dengan penilaian tentang karakteristik pekerjaan, lingkungan, dan pengalaman emosional di tempat kerja. Karyawan yang puas mempunyai penilaian yang baik tentang pekerjaan mereka, berdasarkan pengamatan dan pengalaman mereka. Kepuasan kerja merupakan sekumpulan sikap tentang aspek-aspek yang berbeda dari tugas dan konteks pekerjaan.

Kepuasan kerja pada dasarnya merupakan sesuatu yang bersifat individual Setiap individu memiliki tingkat kepuasan kerja yang berbeda-beda sesuai dengan sistem nilai yang berlaku pada dirinya. Makin tinggi penilaian terhadap kegiatan dirasakan sesuai dengan keinginan individu, maka makin tinggi kepuasannya terhadap kegiatan tersebut. Dengan demikian, kepuasan merupakan evaluasi yang menggambarkan seseorang atas perasaan sikapnya senang atau tidak senang, puas tidak puas dalam bekerja (rivai dan sagala, 2011).

Kepuasan kerja tergantung kesesuaian atau keseimbangan antara yang diharapkan dengan kenyataan. Menurut (Kreitner \& Kinicki, 2014) ada lima faktor yang dapat mempengaruhi kepuasan kerja yaitu sebagai berikut: 1) Pemenuhan kebutuhan (Need fulfillment); 2) Perbedaan (Discrepanicies); 3) Pencapaian nilai (Value attainment); 4) Keadilan (Equity); dan 5) Komponen genetik (Gentic component). Sedangkan menurut (Robbins \& Judge, 2013) faktor-faktor yang menentukan kepuasan kerja adalah: 1) Kerja yang secara mental menantang; 2) Ganjaran yang pantas; 3) Kondisi kerja yang mendukung; 4) Rekan kerja yang mendukung; dan 5) Kesesuaian antara kepribadian pekerjaan.

\section{d. Komitmen Organisasi}

Komitmen organisasi merupakan identifikasi dan keterlibatan seseorang yang relatif kuat terhadap organisasi. Komitmen organisasional adalah keinginan anggota organisasi untuk tetap mempertahankan keanggotaannya dalam organisasi dan bersedia berusaha keras bagi pencapaian tujuan organisasi (Sopiah, 2015). Mowday, Porter dan Steers dalam (Triatna, 2015) mendefinisikan komitmen organisasi sebagai "the relative strength of an individual's identifikacation with and involvement in a particular organization". Definisi ini menunjukan bahwa komitmen organisasi memiliki arti yang lebih luas dari sekedar loyalitas yang pasif, tetapi melibatkan hubungan interaktif dan keinginan karyawan untuk memberikan kontribusi yang berarti pada organisasi. Dalam manajemen organisasi diperlukan hubungan yang lebih baik dan keinginan para karyawan yaitu saling mencintai para karyawan yang mau bekerja dan mempunyai komitmen organisasi yang tinggi. 
Mathis dan Jackson dalam (Sopiah, 2015) memberikan definisi, "Organizational Commitment is the degree to which employees believe in and accept organizational goals and desire to remaint with the organization". (Komitmen organisasional adalah derajat yang mana karyawan percaya dan menerima tujuan-tujuan organisasi dan akan tetap tinggal atau tidak akan meninggalkan organisasi). Mowday dalam (Sopiah, 2015) menyebut komitmen kerja sebagai istilah lain dari komitmen organisasional. Menurut dia, komitmen organisasional merupakan dimensi perilaku penting yang dapat digunakan untuk menilai kecenderungan karyawan untuk bertahan sebagai anggota organisasi.

Lebih lanjut Allen dan Meyer dalam (Darmawan, 2013) mendefinisikan komitmen organisasi sebagai sebuah konsep yang memiliki tiga dimensi, yaitu affective, normative dan continuance commitment. Affective commitment adalah tingkat seberapa jauh seorang karyawan secara emosi terikat, mengenal dan terlibat dalam organisasi. Continuance commitment adalah suatu penilaian terhadap biaya yang terkait dengan meninggalkan organisasi. Normative commitment adalah merujuk kepada tingkat seberapa jauh seseorang secara psychological terikat untuk menjadi karyawan dari sebuah organisasi yang didasarkan kepada perasaan seperi kesetiaan, afeksi, kehangatan, kepemilikan, kebanggan, kesenangan, kebahagiaan dan lain-lain.

Meyer, Allen dan Smith dalam (Sopiah, 2015) mengemukakan bahwa ada tiga komponen komitmen organisasional, yaitu: 1) Affective commitment, terjadi apabila karyawan ingin menjadi bagian dari organisasi karena adanya ikatan emosional; 2) Continuance commitment muncul apabila karyawan tetap bertahan pada suatu organisasi karena membutuhkan gaji dan keuntungan-keuntungan lain, atau karena karyawan tersebut tidak menemukan pekerjaan lain; dan 3) Normative commitment, timbul dari nilai-nilai dalam diri karyawan. Karyawan bertahan menjadi anggota organisasi karena adanya kesadaran bahwa komitmen terhadap organisasi merupakan hal yang seharusnya dilakukan.

\section{Kerangka Berpikir}

Berdasarkan Kajian teori dan hubungan antar variabel maka model atau Conceptual Framework artikel ini dalam rangka menbagunan hipotesis adalah sebagai berikut:

a. Pengaruh lingkungan kerja terhadap kinerja berdasarkan hasil riset: (Novia Cahyani \& Ardana, 2013), (Riyanto et al., 2017), (Purba et al., 2017), dan (Nguyen et al., 2020).

b. Pengaruh kepuasan kerja terhadap kinerja berdasarkan hasil riset: (Masydzulhak et al., 2016), (CIPTODIHARDJO \& IRAWAN, 2013), (Wijaya, 2018), dan (Sari dan Susilo, 2018).

c. Pengaruh komitmen organisasi terhadap kinerja berdasarkan hasil riset: (Masydzulhak et al., 2016), (CIPTODIHARDJO \& IRAWAN, 2013), (Nurandini \& Lataruva, 2014), dan (Suwondo \& Sutanto, 2015)

Dari rumusan masalah penulisan artikel ini dan kajian studi literature review baik dari buku dan artikel yang relevan, maka di perolah rerangka artikel ini seperti di bawah ini. 


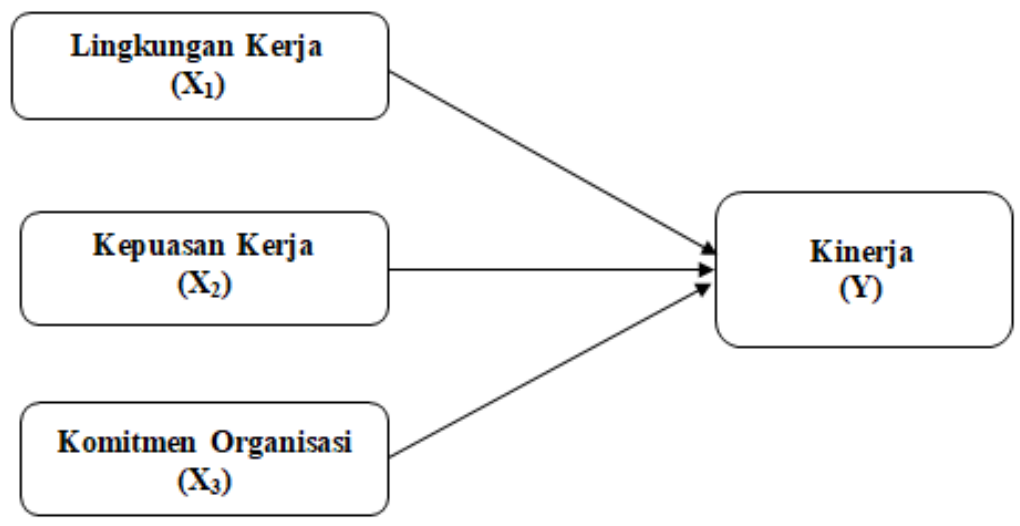

Gambar 1. Kerangka Berpikir

\section{METODE PENELITIAN}

Jenis penelitian ini adalah penelitan kepustakaan (library research), yaitu serangkaian penelitian yang berkenaan dengan metode pengumpulan data pustaka, atau penelitian yang obyek penelitiannya digali melalui beragam informasi kepustakaan (buku, ensiklopedi, jurnal ilmiah, koran, majalah, dan dokumen) (Arikunto, 2014). Penelitian kepustakaan atau kajian literatur (literature review, literature research) merupakan penelitian yang mengkaji atau meninjau secara kritis pengetahuan, gagasan, atau temuan yang terdapat di dalam tubuh literatur berorientasi akademik (academic-oriented literature), serta merumuskan kontribusi teoritis dan metodologisnya untuk topik tertentu (Hapzi Ali. Nandan Limakrisna, 2013). Fokus penelitian kepustakaan adalah menemukan berbagai teori, hukum, dalil, prinsip, atau gagasan yang digunakan untuk menganalisis dan memecahkan pertanyaan penelitian yang dirumuskan. Adapun sifat dari penelitian ini adalah analisis deskriptif, yakni penguraian secara teratur data yang telah diperoleh, kemudian diberikan pemahaman dan penjelasan agar dapat dipahami dengan baik oleh pembaca.

\section{HASIL DAN PEMBAHASAN}

\section{Hubungan Lingkungan Kerja dengan Kinerja}

Lingkungan kerja berkaitan dengan keberadaan sarana dan prasarana serta aspek sosial yang mendukung pekerja dalam melaksanakan pekerjaan. Para anggota organisasi atau pegawai yang terlibat dalam pekerjaan yang sama, berbagi tugas bersama, atau menghadapi pekerjaan yang sama memerlukan faktor lingkungan yang dapat mendukung kebersamaan mereka. Sebagaimana dinyatakan oleh Evans dalam (Shalahuddin, 2016) bahwa lingkungan kerja adalah semua kesempatan yang memungkinkan pegawai memberikan kontribusi untuk berkarya lebih produktif, aman, dan menyenangkan.

Penelitian yang dilakukan (Novia Cahyani \& Ardana, 2013) dan (Nguyen et al., 2020) menunjukkan bahwa penataan ruang yang tepat pada tempat kerja akan berpengaruh terhadap kinerja karyawan. Penataan ruang ini harus didukung dengan distribusi cahaya yang cukup, pemilihan warna dinding yang tepat, sirkulasi udara dan suhu udara sesuai dengan ruangan (Riyanto et al., 2017). Kurangnya distribusi cahaya dalam setiap ruangan karyawan akan mengakibatkan karyawan tidak dapat bekerja dengan cepat dan tepat. Ketenangan bekerja juga diperlukan oleh setiap karyawan untuk melakukan pekerjaannya (Purba et al., 2017). 
Hasil penelitian ini sejalan dengan penelitian yang dilakukan oleh (Novia Cahyani \& Ardana, 2013) menunjukkan bahwa penataan ruang yang tepat pada tempat kerja akan berpengaruh terhadap kinerja karyawan. Penataan ruang ini harus didukung dengan distribusi cahaya yang cukup, pemilihan warna dinding yang tepat, sirkulasi udara dan suhu udara sesuai dengan ruangan (Riyanto et al., 2017). Kurangnya distribusi cahaya dalam setiap ruangan karyawan akan mengakibatkan karyawan tidak dapat bekerja dengan cepat dan tepat. Ketenangan bekerja juga diperlukan oleh setiap karyawan untuk melakukan pekerjaannya (Purba et al., 2017).

Lingkungan kerja berkaitan dengan keberadaan sarana dan prasarana serta aspek sosial yang mendukung pekerja dalam melaksanakan pekerjaan. Para anggota organisasi atau pegawai yang terlibat dalam pekerjaan yang sama, berbagi tugas bersama, atau menghadapi pekerjaan yang sama memerlukan faktor lingkungan yang dapat mendukung kebersamaan mereka. Sebagaimana dinyatakan oleh Evans dalam (Shalahuddin, 2016) bahwa lingkungan kerja adalah semua kesempatan yang memungkinkan pegawai memberikan kontribusi untuk berkarya lebih produktif, aman, dan menyenangkan.

\section{Hubungan Kepuasan Kerja dengan Kinerja}

Kepuasan kerja merupakan prediktor kinerja karena kepuasan kerja mempunyai korelasi moderat dengan kinerja. Pekerja yang puas melakukan pekerjaan lebih baik dalam memenuhi kewajiban seperti tertuang dalam deskripsi pekerjaan. Kenyataan menganjurkan bahwa perasaan positif mendorong kreatifitas, memperbaiki pemecahan masalah dan pengambilan keputusan, dan meningkatkan memori dan menarik berbagai macam informasi tertentu. Perasaan positif juga memperbaiki ketekunan tugas dan menarik lebih banyak bantuan dan dukungan dari rekan sekerja (Harini et al., 2020).

Kepuasan kerja mempunyai pengaruh positif moderat pada kinerja. Orang yang mempunyai tingkat kepuasan kerja lebih tinggi cenderung mempunyai tingkat kinerja lebih tinggi, tingkat citizenship behavior lebih tinggi dan tingkat perilaku kontra produktif lebih rendah (Colquit, LePine dan Wesson dalam (Masydzulhak et al., 2016). Selain itu beberapa penelitian yang dilakukan oleh (Masydzulhak et al., 2016), (CIPTODIHARDJO \& IRAWAN, 2013), (Wijaya, 2018), dan (Sari dan Susilo, 2018) juga mengemukakan bahwasanya kepuasan kerja memiliki pengaruh terhadap kinerja. Dimana hasil penelitiannya mengemukakan bahwasanya jika tingkat kepuasan seseorang dalam bekerja itu baik, maka dengan senatiasa seseorang tersebut akan mampu memberikan hasil kerja yang maksimal demi tujuan organisasi.

Hal ini dapat diartikan pula bahwa semakin tinggi tingkat kepuasan kerja seseorang cenderung mempunyai tingkat kinerja lebih tinggi, tingkat citizenship behavior lebih tinggi dan tingkat perilaku kontra produktif lebih rendah (Colquit, LePine dan Wesson dalam (Masydzulhak et al., 2016).

\section{Hubungan Komitmen Organisasi Dengan Kinerja}

Komitmen organisasional dipandang sebagai suatu orientasi nilai terhadap organisasi yang menunjukkan individu sangat memikirkan dan mengutamakan pekerjaan dan organisasinya. Individu akan berusaha memberikan segala usaha yang dimilikinya dalam rangka membantu organisasi mencapai tujuannya. Fink juga mendefinisikan komitmen 
organisasional sebagai sikap yang muncul dari proses yang disebut sebagai identifikasi yang terjadi ketika seseorang mempunyai pengalaman dengan sesuatu, seseorang, atau beberapa ide sebagai bentuk perpanjangan dari dirinya (Limakrisna et al., 2016).

Komitmen organisasional juga didefinisikan oleh Allen dan Mayer sebagai bentuk kecintaaan karyawan terhadap tempat kerjanya. George and Jones mengatakan bahwa pekerja yang mempunyai komitmen terhadap organisasi senang untuk menjadi anggota organisasi, percaya terhadap organisasi dan mempunyai perasaan yang baik tentang organisasi, dan bersedia bersedia membela organisasi, dan mau melakukan sesuatu yang baik untuk organisasi (Prayetno \& Ali, 2017).

Beberapa hasil penelitian mengungkapkan bahwa komitmen organisasi berpengaruh terhadap kinerja diantaranya yakni penelitian yang dilakukan oleh (Masydzulhak et al., 2016), (CIPTODIHARDJO \& IRAWAN, 2013), (Nurandini \& Lataruva, 2014), dan (Suwondo \& Sutanto, 2015) menyatakan secara signifikan dan positif kinerja dipengaruhi oleh komitmen organisasi. Artinya apabila pegawai memiliki komitmen yang tinggi terhadap organisasi tempat mereka bernaung, maka dengan senatiasa pegawai tersebut akan mampu memberikan hasil kerja yang optimal.

Komitmen organisasi merupakan suatu keadaan dimana seseorang pegawai memihak organisasi tertentu serta tujuan dan keinginannya untuk mempertahankan keanggotaan dalam organisasi tersebut. Komitmen terhadap organisasi artinya lebih dari sekedar keanggotaan formal, karena meliputi sikap menyukai organisasi dan kesediaan untuk mengusahakan tingkat upaya yang lebih tinggi bagi kepentingan organisasinya demi pencapaian tujuan.

Komitmen organisasional pada dasarnya dipandang sebagai suatu orientasi nilai terhadap organisasi yang menunjukkan individu sangat memikirkan dan mengutamakan pekerjaan dan organisasinya. Individu akan berusaha memberikan segala usaha yang dimilikinya dalam rangka membantu organisasi mencapai tujuannya.

\section{KESIMPULAN DAN SARAN}

Berdasarkan rumusan artikel, hasil dan pembahasan yang di kaji dan di bahas pada artikel ini, maka dapat disimpulkan untuk membangun suatu hipoteis guna untuk riset selanjutnya adalah: a) Terdapat pengaruh lingkungan kerja terhadap kinerja; b) Terdapat pengaruh kepuasan kerja terhadap kinerja; dan c) Terdapat pengaruh komitmen organisasi terhadap kinerja.

Berdasarkan kesimpulan di atas, maka saran pada artikel ini adalah bahwa masih banyak faktor lain yang mempengaruhi kinerja seseorang pada semua tipe dan level organisasi, oleh karena itu masih di perlukan kajian yang lebih lanjut untuk melengkapi factor-faktor lain apa sajakah yang dapat memepengaruhi kinerja pegawai.

\section{DAFTAR RUJUKAN}

Anwar Prabu, M. (2017). Manajemen Sumber Daya Manusia Perusahaan, Bandung: PT. In Remaja Rosdakarya.

Arikunto, S. (2014). Prosedur Penelitian: Suatu Pendekatan Penelitian. In Rineka Cipta.

Ciptodihardjo, \& Irawan. (2013). Pengaruh Kepemimpinan, Motivasi, Kepuasan Kerja

Terhadap Komitmen Organisasional Dan Kinerja Karyawan Pada Karyawan

PT.Smartfren,Tbk Di Surabaya. Jurnal Ilmiah Mahasiswa Manajemen.

Darmawan, D. (2013). Prinsip-Prinsip Perilaku Organisasi. In Surabaya Pena Semesta.

Dessler, G. (2017). Manajemen Sumber Daya Manusia. In Pelatihan dan Pengembangan. 
Gomes, F. C. (2003). Manajemen Sumber Daya Manusia. In Andi.

Hapzi Ali. Nandan Limakrisna. (2013). Metodologi Penelitian ( Petunjuk Praktis Untuk Pemecahan Masalah Bisnis, Penyusunan Skripsi, Tesis, dan Disertasi. In Deeppublish: Yogyakarta.

Harini, S., Hamidah, Luddin, M. R., \& Ali, H. (2020). Analysis supply chain management factors of lecturer's turnover phenomenon. International Journal of Supply Chain Management.

Hasibuan, M. (2016). Manajemen Dasar Pengertian dan Masalah Edisi Ke-7. In Jakarta: Bumi Aksara.

Kreitner, R., \& Kinicki, A. (2014). Perilaku Organisasi Organizational Behavior. In 1.

Limakrisna, N., Noor, Z. Z., \& Ali, H. (2016). Model of employee performance: The empirical study at civil servants in government of west java province. International Journal of Economic Research.

Masydzulhak, P. D., Ali, P. D. H., \& Anggraeni, L. D. (2016). The Influence of work Motivationand Job Satisfaction on Employee Performance and Organizational Commitment Satisfaction as an Intervening Variable in PT. Asian Isuzu Casting Center. In Journal of Research in Business and Management.

Mathis, R. L., \& Jackson, J. H. (2012). Manajemen Sumber Daya Manusia. In Manajemen Sumber Daya Manusia.

McShane, S. L., \& Von Glinow, M. A. Y. (2018). Organizational Behavior: Emerging Knowledge. Global Reality (8th) Edition. In McGraw-Hill.

Nguyen, P. T., Yandi, A., \& Mahaputra, M. R. (2020). Factors That Influence Employee Performance: Motivation, Leadership, Environment, Culture Organization, Work Achievement, Competence And Compensation (A Study Of Human Resource Management Literature Studies). Dinasti International Journal of Digital Business Management.

Nitisemito, \& Alex, S. (2001). Manajemen Sumber Daya Manusia. In Manajemen Personalia.

Novia Cahyani, P., \& Ardana, I. (2013). Pengaruh Lingkungan Kerja Fisik, Gaya Kepemimpinan Dan Insentif Finansial Terhadap Kinerja Pegawai Non Medis Pada Rumah Sakit Balimed Denpasar. E-Jurnal Manajemen Universitas Udayana.

Prayetno, S., \& Ali, H. (2017). Analysis of advocates organizational commitment and advocates work motivation to advocates performance and its impact on performance advocates office. International Journal of Economic Research.

Purba, C. B., Arzio, \& Ali, H. (2017). The influence of compensation, working environment and organization culture on working productivity of BPJS (workers social security agency) employment staff in Rawamangun Branch. Man in India.

rivai dan sagala. (2011). Manajemen sumber daya manusiauntuk perusahaan dari teori ke praktek. Rekrutmen.

Rivai Veitzhal. (2013). Manajemen Sumber Daya Manusia. Manajemen Sumber Daya Manusia Untuk Perusahaan Dari Teori Ke Praktik.

Riyanto, S., Sutrisno, A., \& Ali, H. (2017). The Impact of Working Motivation and Working Environment on Employees Performance in Indonesia Stock Exchange. International Review of Management and Marketing.

Robbins, S. P., \& Judge, T. A. (2013). Organizational Behavior 15th Edition. In The Curated Reference Collection in Neuroscience and Biobehavioral Psychology.

Sedarmayanti. (2017). Perencanaan Dan Pengembangan Sumber Daya Manusia Untuk Meningkatkan Kompetensi, Kinerja, Dan Produktivitas Kerja. In Perencanaan Dan Pengembangan Sumber Daya Manusia Untuk Meningkatkan Kompetensi, Kinerja, Dan 
Produktivitas Kerja.

Shalahuddin, A. (2016). Pengaruh Kepemimpinan Dan Lingkungan Kerja Terhadap Komitmen Organisasional Dan Kinerja Karyawan PT. Sumber Djantin Di Kalimantan Barat. Jurnal Manajemen Teori Dan Terapan| Journal of Theory and Applied Management. https://doi.org/10.20473/jmtt.v6i2.2665

Simanjuntak, P. J. (2005). Manajemen dan Evaluasi Kinerja. In FE UI.

Suwondo, D. I., \& Sutanto, E. M. (2015). Hubungan Lingkungan Kerja, Disiplin Kerja, Dan Kinerja Karyawan. Jurnal Manajemen Dan Kewirausahaan (Journal of Management and Entrepreneurship). https://doi.org/10.9744/jmk.17.2.145-154

Wijaya, I. K. (2018). Pengaruh Kepuasan Kerja Terhadap Kinerja Karyawan Cv Bukit Sanomas. Agora. 